\title{
Performance adjustment: a key to the survival of existing buildings
}

\author{
R. Lione ${ }^{1} \&$ F. Minutoli ${ }^{2}$ \\ ${ }^{1}$ Department of Civil Engineering, Informatics, Construction, \\ Environmental and Applied Mathematics, Messina University, Italy \\ ${ }^{2}$ Department of Electronic Engineering, Chemical and \\ Industrial Engineering, Messina University, Italy
}

\begin{abstract}
The energy efficiency of the existing housing is the subject matter of this paper. Notably, we focus on a few designs that solved the thermal insulation problems. Their ways unobtrusively suggest new readings of the buildings: all these interpretations meet the current requirements but from various perspectives: technical-materic, requisite-functional and stylish-chromatic.

Keywords: recovery, residential buildings, thermal transmittance.
\end{abstract}

\section{Reasons}

All was quite clear!

The reasons behind eco-friendliness, sociological concern, etc., the mastery (real or alleged), the land consumption and the past building percentage statistics, the (gloomy) prediction where our world is heading to.

Therefore we believed it appropriate to get into a research stream devoted to "properly" answering the problems that arise in the existing buildings, so fragile in a seismic sense and so unfit for managing energy consumption, not to mention the shortcomings both formal and functional...

Having read a lot and, into the bargain, having written a few papers on the subject [1-3], we are clear about the big picture: no doubt about looking for and devising systems suited to revitalizing old buildings or obsolete in any way (perhaps the French "age" would better convey the real meaning, all the more so since this obsolescence not necessarily is caused by the age). This has brought us to the conclusion that it is always possible to endow an obsolete building with 
new or renewed functions and with performances which it has never had and, in such way, conferring a second youth on a structure that, if nothing else, deserves credit for being already in place and, as such, not demanding new soil or resources.

In the meantime, we tried to devise both technical and constructional systems by comparing materials, procedures, layering and parameters (from the insulating sheets in the EIFS to the multilayered boards, from specific heat capacity to vapour permeability).

So what is the doubt? Wherein lies the problem?

In the costs of course, but we dealt with this problem and we came up with multiple hypotheses or in some cases we embraced "tried and tested" solutions [4]. Actually, it is possible to foreshadow plausible scenarios.

In the increasingly faster obsolescence of materials and constructive methods, of course: today, the most advanced solution could became utterly outdated just by tomorrow, the risk is that as soon as the usually long decisional process (just look at a commonhold) is accomplished, the picked key would rattle in the lock. (Finding a thinner insulation formed by 1-3 layers of polyethylene, air bubbles and two heat-sealed film of $\mathrm{Al}(7-8 \mathrm{~mm})$, we were "overwhelmed" by the paint Thermoshield that allows results comparable with a thickness of $1 \mathrm{~mm}$.) Eventually, against the background of the experiences gained so far in Italy and in other countries, the true problem stands out sharply: the merely cultural one, intrinsic to the consistence amongst actions and unmeasurable qualities; first, among the latter, historical identity (lesser history, often) hand in hand with the materic identity.

Nobody contemplates reviving the quarrel between Ruskin and Viollet-LeDuc, but sometimes one tends to dismiss the danger of sheltering oneself behind a side of the fence and to overlook the blurred boundary between extreme views. Sometimes one forgets that should the ancientness constitute the ultimate boundary for the freedom to act on an architectural structure, many buildings, which today one could modify as one pleases, soon would be in the off limit list (the automatic listing as Historic and Art Property is triggered just beyond the fifty years threshold).

In the same way, one forgets that overcoming the dichotomy between monument and listed urban fabric was regarded as a momentous achievement and, on this basis, it was possible to discern between obsessive conservation and reuse (albeit sometimes unorthodox and seldom free of typological and/or materic losses).

Where is the boundary? What is the operating perimeter? To what extent the "intervention distinguishability" - the conservation old rallying cry could serve as an alibi for whatever disfigurement?

When the continuity in the historical heritage (a mixture of building typology, layout, praxis, skills: in one word, tradition) could or must be sacrificed for the sake of energy efficiency, of anti-seismic improvement, of functional upgrading?

Which are the conceptual differences between a $19^{\text {th }}$ century farmhouse and a commonhold built at the edge of a large city? 
So where is the dividing line between what one can do for the sake of the health of our planet and the regard to what our fathers (or far ancestors; hardly anything changes) have entrusted us with - a heritage through which we read their lives and our very history?

As usual, we could write a great deal without succeeding in codifying a set of rules for good design!

A reading attempt of a few fulfilled designs is more useful, or perhaps just easier. We believe their analysis could provide us with some kind of roadmap or, at least, with better analytical skills.

\section{Implementation}

Who is the good designer? Why did he become a good one? Which are his/her works?

Once we spotted him or her and once we laid aside our egotistical conceit, why do we not pursue his "sure ways" ensuing as a result of so great theory and so much practice?

The research we carried out has made us face many prestigious names, awardwinning firms, recognized by the best sectorial journals both National and International. However, many designs, which on a first browsing looked innovative and even startling, in the end of the day, they did not often meet, perhaps because of too much boldness both technological and compositional, the designer authority: additions, subtractions, superpositions, conversions and extensions. Sometimes, these interventions actually hinder the revitalisation process. Why? Mainly because of conflicts between technical arrangements and materic appearance, requirements and functions, shaping and chromatic solutions, lifespan (too short sometimes) and cost.

However, we do not mean to take a severe conservative approach, we believe that dialectical confrontation between the new and the existing ensures, in fact, the continuity of a building. Therefore, we focused on revitalisation processes, implemented, in the last decade, in Italy, which have preserved the primitive proposed use - residential use, in our case - and which, in the meantime, upgraded the residual performance to meet the new boundary conditions.

Therefore, we critically analyzed the construction details, the selected technical solutions and the layering of the new architectonic elements.

We have picked out a few which, we believe, may provide suggestions for implementing a proper method of upgrading the existing residential buildings.

Obviously, we have taken into account their compositional outcome, their intervention strategy and their implementation.

The status quo ante and the motivation that aimed the revitalisation project are briefly addressed.

We are looking at residential buildings because of the widespread steady awareness - both in Italy and in many other European countries - that reusing the enormous existing house asset would be a better approach to the housing problem. However, most of this asset is obsolescent because it does not meet the current environmental and anti-seismic regulations; the natural decline aside. 
The 2011 ISTAT data point out that $90 \%$ out of 11.7 million dwelling units is older than 20 years and $60 \%$ is older than 40 years so unplanned maintenance is due in the former, structural and functional upgrading in the latter. In Italy, a good percentage of these houses was refurbished thanks to the State's incentive measures. However, almost five million dwellings are in need of performance updating to meet the current legislation on energy efficiency.

More precisely:

- $5.6 \%$ of this five million is in a critical state from both a structural and functional perspective and, moreover, it is "highly energy consuming;

- $40.6 \%$ is in need of unplanned maintenance and it is "energy consuming";

- $53 \%$ is in need of ordinary maintenance and it is "averagely energy consuming".

The designs shown in the next pages share the same aim: attaining lower energy consumption through up-to-date techniques while making a proper assessment of the technologies and building process implemented in the early construction.

We have restricted the selection to "normal buildings", located in small villages or in an urban fabric characterized by scattered and quite unremarkable developments.

By dealing with and solving the complex interaction between preexisting artifacts and modern action, these designs, in our opinion, transformed these "run-of-the-mill" buildings in noteworthy attainments.

For each of the reported designs, we evaluated the steady state thermal transmittance, before and after the revitalisation intervention, in the case of both the vertical and the horizontal closing elements. Where it needed, we evaluated the linear transmittance of the thermal bridges too, as per UNI EN 14683 and UNI 7357:74.

A first instance is in the 2004 work of Geza firm in Tarcento (Udine) on a district marked by early $20^{\text {th }}$ century eclectic buildings. (The project concerns a 6,300 sq. m private parcel: three buildings are on the property: the main house, the annex and the greenhouse. The latter involved the demolition of a large
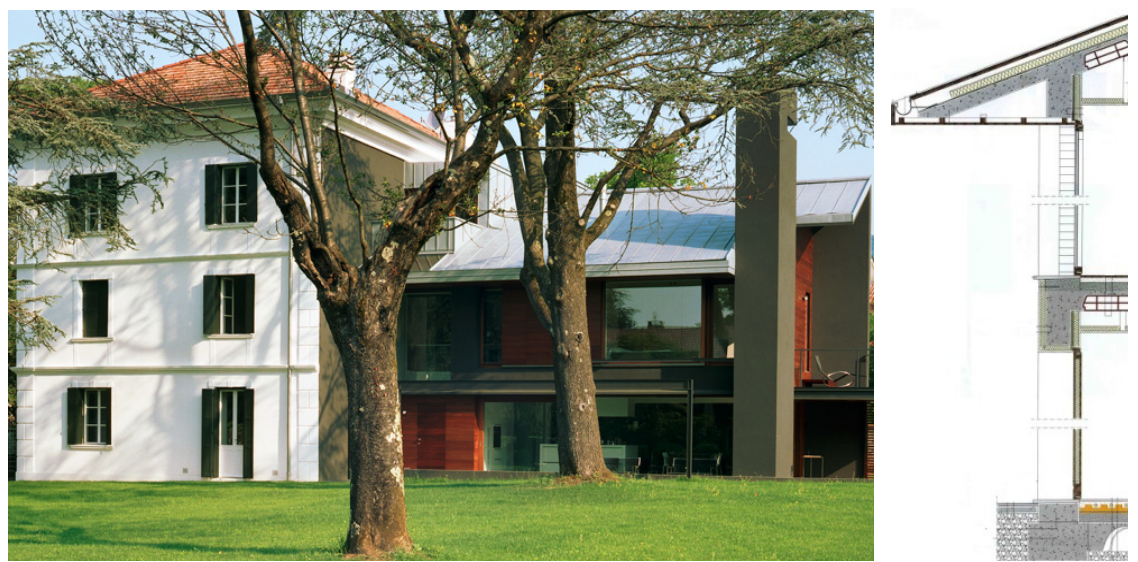

Figure 1: Tarcento: south façade and construction detail. 
addition to the main house, the construction of a new more appropriate extension against the main house, and the structural renovation of the historic part of the building.) The extension of a highly symmetric and even mansion achieved by juxtaposing a new volume, different in terms of materials, openings, colours, rhythm... and yet able to make the whole building harmonious. The modernity is outlined by the recession of both the North and South blackened new fronts with respect to the white elevations of the pristine mansion. Up to date energy efficiency has been achieved by an accurate study both formal and technological. Its main aim was the removal of all the thermal bridges.

Laid on a ventilation space, the bottom horizontal leaf, with its slate flooring on micro-cellular concrete screed which in turn integrates the under-floor heating, ensures a thermal transmittance of $0.29 \mathrm{~W} / \mathrm{m}^{2} \mathrm{~K}$ vs. $0.37 \mathrm{~W} / \mathrm{m}^{2} \mathrm{~K}$ we found in the mansion.

The intermediate horizontal closing has a floor boarding made of merbau wood and a bottom surface made of gypsum plasterboard with rock wool above: the thermal transmittance is $0.24 \mathrm{~W} / \mathrm{m}^{2} \mathrm{~K}$ vs. $0.31 \mathrm{~W} / \mathrm{m}^{2} \mathrm{~K}$ of the analogue structure in the mansion.

The sloping outer sub-horizontal closing (23\% pitch) is made of an external layer of $\mathrm{Zn}-\mathrm{Cu}-\mathrm{Ti}$ alloy thin plates branded Rheinzink. According to the manufacturer, this material is environmentally friendly. (Rheinzink material has been certified by the Institut Bauen und Umwelt as "ecological and sustainable"; the excellent ecological balance is documented in DIN ISO 14025, Type III and EN 18504 (see http://www.rheinzink.it/).) The alloy plates are seamed on a continuous support layer that consists of a waterproof/breathable membrane fixed to wooden planking. This latter rests on white deal battens, below is a rigid insulation on a vapour barrier. Eventually, a slab made of reinforced concrete lightened by clay hollow bricks acts as structural support.

For this layered structure, we reckoned that thermal transmittance has to be $0.28 \mathrm{~W} / \mathrm{m}^{2} \mathrm{~K}$ vs. $0.66 \mathrm{~W} / \mathrm{m}^{2} \mathrm{~K}$ of the analogue structure in the mansion.

As of the vertical closing elements, a double EIFS ensures a transmittance that falls below the relevant ruled limits. Its stratigraphy is depicted in tab. 1. Its $410 \mathrm{~mm}$ thickness provides: thermal resistance equal to $3.527 \mathrm{~m}^{2} \mathrm{~K} / \mathrm{W}$, area mass equal to $655.125 \mathrm{Kg} / \mathrm{m}^{2}$, transmittance equal to $0.284 \mathrm{~W} / \mathrm{m}^{2} \mathrm{~K}$ vs. $0.39 \mathrm{~W} / \mathrm{m}^{2} \mathrm{~K}$ we find in the mansion. These values are consistent with the DPR 59/09 requirements for both E and GG 2702 climatic zone. It is worth noting that these rules were issued after completion of the building.

Different are the solutions that Michele Arnaboldi devises in his renovation of Pianezzo hamlet [5] (Canton Ticino, $\mathrm{CH}$ ). The hamlet consists of seven gneiss stone dwellings. The architect chose to preserve the oldest five dwellings and to demolish the two most recent dwellings that, moreover, were in a critical structural state.

Even in the apparent contradiction arising from the two actions, preserving and demolishing, it is possible to trace logic continuity in the design action: both on the technological side and on the material one. Actually, this design succeeds in the upgrading all the performance characteristics of a rural fabric that before was near to collapse. 
584 Structural Studies, Repairs and Maintenance of Heritage Architecture XIV

Table 1: Tarcento: technical solutions in vertical closing elements.

\begin{tabular}{|c|c|c|c|c|c|}
\hline $\begin{array}{l}\text { Stratigraphic } \\
\text { analysis }\end{array}$ & $\begin{array}{l}\text { Thickness } \\
(\mathrm{mm})\end{array}$ & $\begin{array}{c}\lambda \\
(\mathrm{W} / \mathrm{mK})\end{array}$ & $\begin{array}{c}\mathrm{m.v} . \\
\left(\mathrm{Kg} / \mathrm{m}^{3}\right)\end{array}$ & $\begin{array}{c}\mathrm{P} \\
(\mathrm{Kg} / \mathrm{msPa})\end{array}$ & $\begin{array}{c}\mathrm{R} \\
\left(\mathrm{m}^{2} \mathrm{~K} / \mathrm{W}\right)\end{array}$ \\
\hline External admittance & & 7.7 & & & 0.13 \\
\hline Plasterboard & 12.5 & 0.21 & 900 & 23 & 0.06 \\
\hline Rock wool insulation & 50 & 0.037 & 125 & 150 & 1.351 \\
\hline Rock wool insulation & 25 & 0.037 & 125 & 150 & 0.676 \\
\hline $\begin{array}{l}\text { Reinforced concrete } \\
\text { beam }\end{array}$ & 250 & 1.909 & 2400 & 1.3 & 0.131 \\
\hline $\begin{array}{l}\text { Panel of wood wool } \\
\text { mineralized }\end{array}$ & 50 & 0.045 & 130 & 8 & 1.111 \\
\hline Painted plaster & 20 & 0.70 & 1400 & 18 & 0.029 \\
\hline Internal admittance & & 25 & & & 0.04 \\
\hline
\end{tabular}
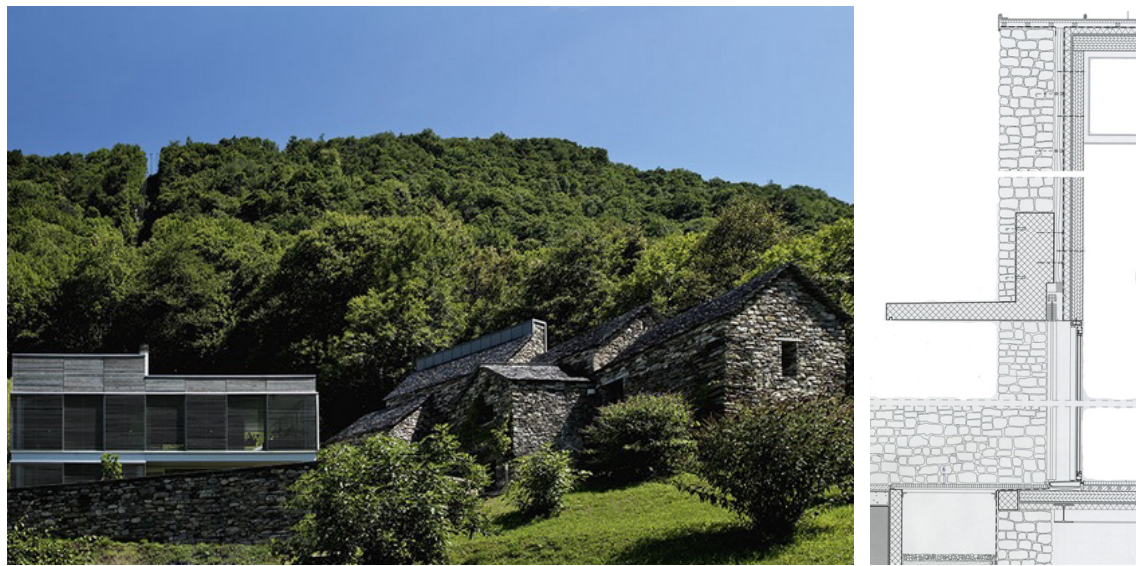

Figure 2: Pianezzo: village and construction detail of gneiss stone dwelling.

As far as the five old dwellings were concerned, the architect chose for an internal cladding made of self-supporting wooden boards so that the existing walls have had to be affected only by consolidating and maintaining works. The two dilapidated buildings have been replaced by a single two stories building with a structural wooden and steel framework and low-E glazed walls shielded by a wooden brise-soleil. Reinforced concrete is restricted to the foundations and the stairs for the vertical connection. In fact, the horizontal partitions as well the flat roof have a WBP pine plywood structural framework.

In particular, the stratigraphy of flat roof is laid as follow (internal layer first):

1. gypsum plasterboard (suspended ceiling);

2. crawlspace;

3. wooden slab;

4. rock wool insulation layer; 
5. waterproof membrane;

6. geotexile protective layer;

7. gravel ballast.

A metal flashing with special drip edge turns the rainwater away.

The outer shell reveals its lightness in the full-height glazed sliding elements, metal uprights acts as framework for the Douglas fir slats of the wooden shading system.

The roofing system of the preserved units consists of self-bearing wooden boards fitted on the transversal elements of the internal cladding. This latter maintains a clearance from the existing stone walls so that the resulting space could allow for the technical systems and for a natural air flow. The detailed stratigraphy of the remaining layers is as follow (internal layer first):

1. vapour barrier (tight fitted to the sloping slab);

2. rock wool insulation layer;

3. waterproof membrane;

4. wooden rafters (which form a ventilated support);

5. transversal wooden battens bearing the stone slating (made of piode).

Table 2: Pianezzo: technical solutions in vertical closing elements.

\begin{tabular}{|c|c|c|c|c|c|}
\hline $\begin{array}{l}\text { Stratigraphic } \\
\text { analysis }\end{array}$ & $\begin{array}{l}\text { Thickness } \\
\text { (mm) }\end{array}$ & $\begin{array}{c}\lambda \\
(\mathrm{W} / \mathrm{mK})\end{array}$ & $\begin{array}{c}\mathrm{m} . \mathrm{v} . \\
\left(\mathrm{Kg} / \mathrm{m}^{3}\right)\end{array}$ & $\begin{array}{c}\mathrm{P} \\
(\mathrm{Kg} / \mathrm{msPa})\end{array}$ & $\begin{array}{c}\mathrm{R} \\
\left(\mathrm{m}^{2} \mathrm{~K} / \mathrm{W}\right)\end{array}$ \\
\hline External admittance & & 7.7 & & & 0.13 \\
\hline Pine plywood panel & 100 & 0.144 & 550 & 4.50 & 0.694 \\
\hline Rock wool insulation & 50 & 0.037 & 125 & 150 & 1.351 \\
\hline $\begin{array}{l}\text { Waterproofing } \\
\text { membrane }\end{array}$ & 10 & 0.50 & 1600 & 0.01 & 0.02 \\
\hline Wooden support & 80 & 0.144 & 550 & 4.5 & 0.556 \\
\hline Layer ventilation & 20 & 0.15 & 1 & 193 & 0.133 \\
\hline Stone masonry & 500 & 3.50 & 2700 & 0.02 & 0.143 \\
\hline Internal admittance & & 25 & & & 0.04 \\
\hline
\end{tabular}

The double shell technology allowed for assigning new functions to the interiors, preserving, in the meantime, the existing building morphology and the ancient facing walls. Moreover, on-site works were simplified and shortened as the wooden cladding elements had been cut in a workshop.

The double shell allowed for an aluminium argon filled double-low-E glazed roof-light as long as the ridge of the roof of the atelier unit; the opaque portions and the relationship with the rest of the roof were arranged, as in the Tarcento instance by $\mathrm{Zn}-\mathrm{Cu}$-Ti alloy thin plates, whose colour closely resembles the one of the "piode" slates. Under these plates, seamlessly runs the insulation layer.

Considering the climatic zone, the low-e argon filled double-glazing and the chosen thermal insulation system were fundamental to the hamlet environmentally friendly renewal. 
Arch. Marco Camplani conceived a regeneration project (2005) concerning a former single-family house in Bergamo [6]. His design took the form of a conversion attaining more housing units.

Particularly, the ground floor houses technical areas, two apartments are on the first floor and a larger apartment occupies the whole top floor. This latter floor originated by substituting the existing sloping roof with a flat one.
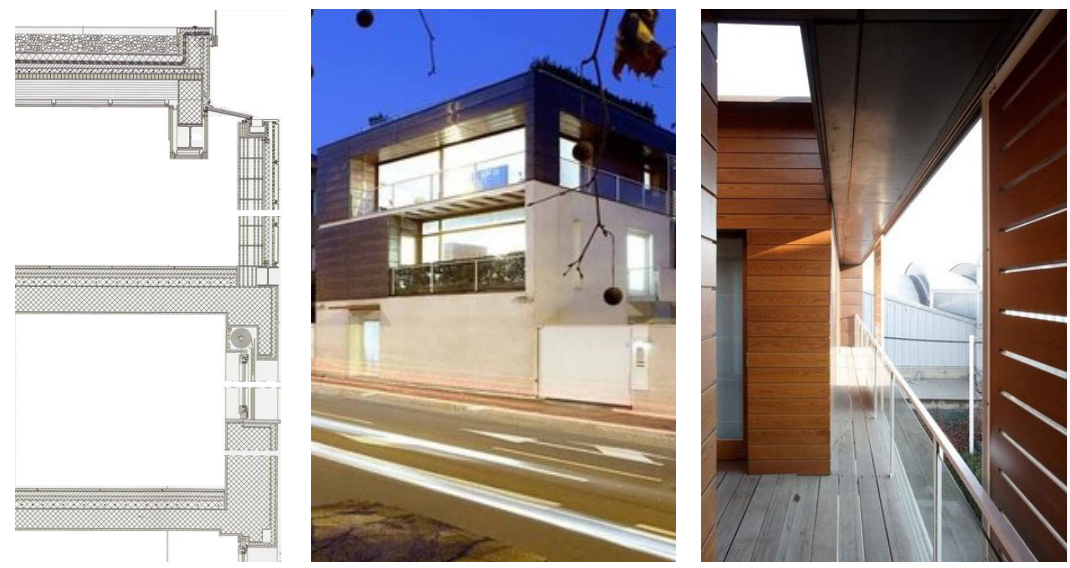

Figure 3: Bergamo: view and construction detail of housing recovered.

The outer cladding of the first two stories was upgraded by a plastered EIFS. The third storey sports a different vertical closing:

1. ventilated wall consisting (see tab. 3) of a bearing layer (hollow clay bricks);

2. first insulating layer made of polystyrene boards framed in a glulam framework;

3. ventilated cavity;

4. OSB phenolic boards fixed to the external framework uprights;

5. final cladding made of Tecu pre-oxidized copper planks.

Table 3: Bergamo: solutions in vertical closing elements of the third level.

\begin{tabular}{|c|c|c|c|c|c|}
\hline $\begin{array}{c}\text { Stratigraphic } \\
\text { analysis }\end{array}$ & $\begin{array}{c}\text { Thickness } \\
(\mathrm{mm})\end{array}$ & $\begin{array}{c}\lambda \\
(\mathrm{W} / \mathrm{mK})\end{array}$ & $\begin{array}{c}\mathrm{m} . \mathrm{v} . \\
\left(\mathrm{Kg} / \mathrm{m}^{3}\right)\end{array}$ & $\begin{array}{c}\mathrm{P} \\
(\mathrm{Kg} / \mathrm{msPa})\end{array}$ & $\begin{array}{c}\mathrm{R} \\
\left(\mathrm{m}^{2} \mathrm{~K} / \mathrm{W}\right)\end{array}$ \\
\hline External admittance & & 7.7 & & & 0.13 \\
\hline Plaster & 20 & 0.7 & 1400 & 18 & 0.029 \\
\hline Brick blocks & 240 & 0.426 & 1400 & 25.71 & 0.587 \\
\hline $\begin{array}{c}\text { Panels high density } \\
\text { polystyrene }\end{array}$ & 40 & 0.034 & 50 & 1.56 & 1.176 \\
\hline $\begin{array}{c}\text { Layer ventilation } \\
\text { Phenolic panels }\end{array}$ & 40 & 0.28 & 1 & 193 & 0.143 \\
\hline $\begin{array}{l}\text { Copper staves } \\
\text { Internal admittance }\end{array}$ & 20 & 380 & 8900 & 1 & 0.435 \\
\hline \multicolumn{2}{|c|}{ The thermal transmittance $0.393 \mathrm{~W} / \mathrm{m}^{2} \mathrm{~K}$ vs. $1.07 \mathrm{~W} / \mathrm{m}^{2} \mathrm{~K}$ before recovery. } \\
\hline
\end{tabular}


This stratigraphy ensures, with a $360 \mathrm{~mm}$ thickness, a transmittance value of $0.393 \mathrm{~W} / \mathrm{m}^{2} \mathrm{~K}$ vs. $1.07 \mathrm{~W} / \mathrm{m}^{2} \mathrm{~K}$ of the former layout. Its thermal resistance amounts to $2.54 \mathrm{~m}^{2} \mathrm{~K} / \mathrm{W}$, while its surface mass is $399.44 \mathrm{Kg} / \mathrm{m}^{2}$.

The new roof supported by a steel main framework and a secondary glulam one allows for a roof garden. This garden makes up for a former one at street level that was expropriated to make way for a larger road.

The stratigraphy above the bearing framework is as follows:

1. high strength concrete decking poured on $50 \mathrm{~mm}$ OSB boards;

2. lightweight concrete sloping screed;

3. waterproof PVC membrane;

4. high density $60 \mathrm{~mm}$ polystyrene boards;

5. nonwoven fabric sliding layer;

6. $250 \mathrm{~mm}$ of soil.

Those layers, all together, ensure a good thermal and acoustic insulation. Close attention was paid to doors and windows whose frames are made of thermal insulated timber-aluminium profiles, while a triple glazing is laid in this order: outer selective glass pane with PVB $1.52 \mathrm{~mm}$ film for sunlight and noise abatement, argon filled cavity, tempered glass pane, sulphur hexafluoride filled cavity, inner low-E pane.

In all these designs, the main task is to deal with the harsh winter climate and the summer cooling bill is, in comparison, negligible. Therefore, it appears consistent with a low mean temperature the passive house concept where airtightness and high specific mass throughout the outer boundary is required.

However, this choice could be an utterly unsatisfactory solution where one must deal with the Mediterranean climate. As matter of fact, this climatic area asks for systems that allow for the quickest disposal of the thermal overload stored within the boundary diaphragm during an average summer day. Accordingly, the insulation system layout has to be devised carefully; care being taken in choosing materials that could ensure a low surface mass where higher is solar irradiance. Nevertheless, still nowadays, this is not often accomplished.

However, here is an instance of renovation design, carried out in Sicily - the 2014 renovation of a section of a $19^{\text {th }}$ century building in Ragusa - where the energy efficiency is the main task but the reduction of heat loss and the thermal bridge correction is cleverly balanced.

In fact, a total correction of the thermal bridges during the summer would be quite unappreciable (around 2\%) and in any case, not enough to justify the higher building and maintenance costs of avant-garde technologies.

Therefore, no insulated connector for the balconies, no double insulation for the walls, no triple glazing: instead, priority was given to the outer shell thermal inertia, this way ensuring a time lag in the thermal wave.

A light colour coating of the external surfaces results in a higher reflectance and a bunch of technical-compositional measures such as the exposure with regard to the sun, the moderating effect of the sea nearby, natural ventilation, loggias, balconies, verandas, ... still functional to overall energy saving.

This design, devised by Giuseppe Gurrieri and Valentina Giampiccolo, amid an urban fabric of historic interest that consists of an ensemble of minor 

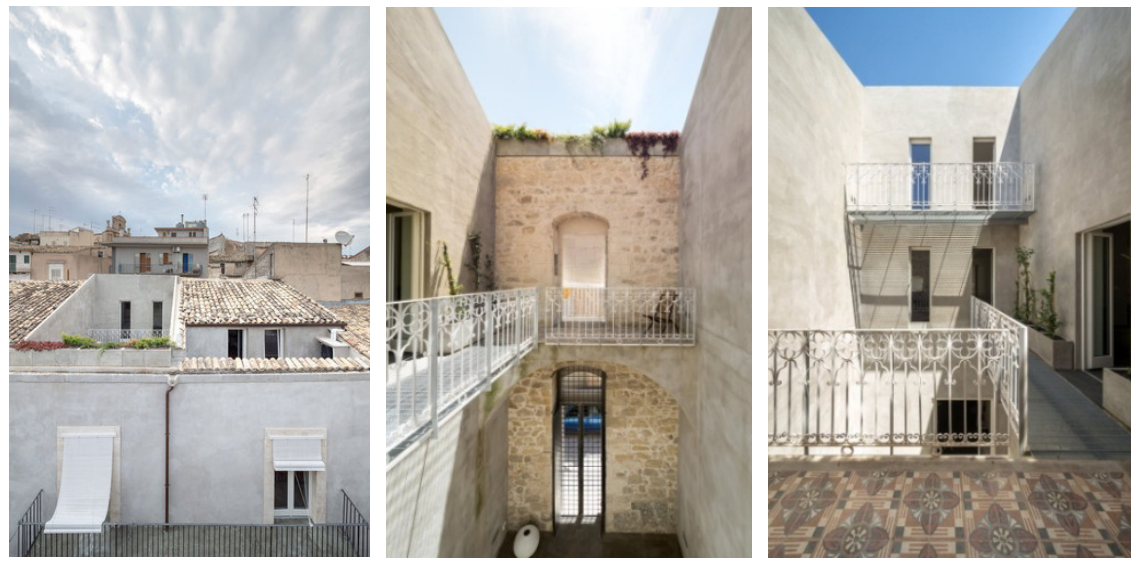

Figure 4: Ragusa: images of the recovered building.

architectural specimen (lesser but not the least important), aims to the best use of the sun exposure conditions and to ensure the natural lighting of the ground floor. These spaces formerly contained a dairy plant and they utterly lacked direct sunlight. (The project resulted in the October 2014 winner of the third edition of the Prize RI.U.SO, banished by the National Council of Architects, Planners, Landscapers and Conservationists.)

The main move, in this way, was attaining an inner courtyard, distinctive feature of the Mediterranean architectural tradition, by reducing the interior living space.

Thus pursuing a sustainable renovation and alteration strategy and allowing for better distribution of the inner spaces, enhanced privacy and better exposure with regard to the sun. The recession of the walls to place the courtyard, in fact, solved the problems ensuing from being the near buildings too close. Moreover, it has allowed new openings in the south and southeast facing walls, behind which are kitchen and living room on the first floor and the sleeping quarters on the second floor. The courtyard makes for the new entrance to the house and, in the meantime, it allows for better natural ventilation ensuring a better energy performance without altering the ancient shell: the $550 \mathrm{~mm}$ masonry is not affected; only the plastering is redone with natural hydraulic lime, the stone parts scrubbed and protected. New timber windows joinery are fitted in place.

The new shell that encloses the courtyard is structured as a "classic" cavity wall, with inner insulation and housing for the technical systems. Its stratigraphy (see tab. 4) in $400 \mathrm{~mm}$ thickness ensures a thermal resistance of $2.126 \mathrm{~m}^{2} \mathrm{~K} / \mathrm{W}$ and a surface mass of $400.38 \mathrm{Kg} / \mathrm{m}^{2}$. The resulting transmittance is $0.47 \mathrm{~W} / \mathrm{m}^{2} \mathrm{~K}$, higher the coded $1.13 \mathrm{~W} / \mathrm{m}^{2} \mathrm{~K}$ threshold for $\mathrm{C}$ and GG 1324 climatic area. It is higher than existing walls transmittance: $0.40 \mathrm{~W} / \mathrm{m}^{2} \mathrm{~K}$.

However, notwithstanding this higher transmittance, we note that, unlike the designs in Pianezzo, Tarcento and Bergamo where the Glaser diagram indicates a vapour condensing possibility, although within the admissible range, here the Glaser diagram rules out any potential superficial and/or interstitial vapour 
condensing (see fig. 5). (Proper design of the buildings in Pianezzo, Tarcento and Bergamo, makes it possible to ensure, in accordance with the UNI EN ISO 13788 , breathability which favors, in summer, the drying of the water vapor condensed.)

Table 4: Ragusa: technical solutions in vertical closing elements.

\begin{tabular}{|c|c|c|c|c|c|}
\hline $\begin{array}{c}\text { Stratigraphic } \\
\text { analysis }\end{array}$ & $\begin{array}{c}\text { Thickness } \\
(\mathrm{mm})\end{array}$ & $\begin{array}{c}\lambda \\
(\mathrm{W} / \mathrm{mK})\end{array}$ & $\begin{array}{c}\mathrm{m} . \mathrm{v} . \\
\left(\mathrm{Kg} / \mathrm{m}^{3}\right)\end{array}$ & $\begin{array}{c}\mathrm{P} \\
(\mathrm{Kg} / \mathrm{msPa})\end{array}$ & $\begin{array}{c}\mathrm{R} \\
\left(\mathrm{m}^{2} \mathrm{~K} / \mathrm{W}\right)\end{array}$ \\
\hline External admittance & & 7.7 & & & 0.13 \\
\hline Panel plasterboard & 12.5 & 0.21 & 900 & 23 & 0.06 \\
\hline Brickwork & 120 & 0.328 & 1800 & 20.57 & 0.366 \\
\hline Interspace & 130 & 0.56 & 1 & 193 & 0.232 \\
\hline Polyurethane panel & 40 & 0.039 & 25 & 3.75 & 1.026 \\
\hline Brickwork & 80 & 0.328 & 1800 & 20.57 & 0.244 \\
\hline $\begin{array}{c}\text { Plaster } \\
\text { Internal admittance }\end{array}$ & 20 & 0.7 & 1400 & 18 & 0.029 \\
\hline \multicolumn{2}{|c|}{ The thermal transmittance $0.47 \mathrm{~W} / \mathrm{m}^{2} \mathrm{~K}$ vs. $1.13 \mathrm{~W} / \mathrm{m}^{2} \mathrm{~K}$ before recovery } \\
\hline
\end{tabular}

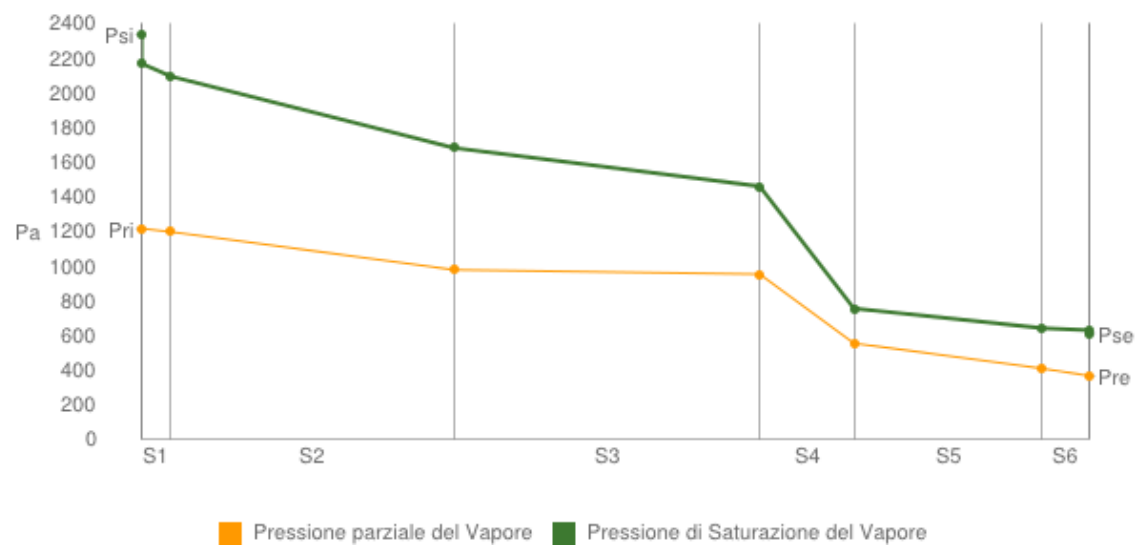

Figure 5: Ragusa: Glaser diagram of the vertical closing elements.

Beyond the north wall, colder and dank during the winter months, is a vertical distribution element that deals only with transient stay and at the same time allows for a recession of the living space.

The new volumetric and spatial shaping finds its fulcrum in the courtyard where, amid contrasting elements such as up-to-date metal gratings. Liberty railings or patterned cement tiles, stands out the conversion of the ancient pool for the cheese brining in raining water reservoirs. Water to be used in the toilets and for the irrigation system. 


\section{Conclusion}

Actually, what we meant to show is the non-existence of a true conclusion; nay it would not be correct to find it. (The contribution was developed in a unitary way by the authors, see section 1 written by Lione and sections 2 and 3 by Minutoli.) As matter of fact, in the design process nothing can be taken by default because an ad hoc solution has to be identified case-by-case, by taking into account historic, geographic, cultural, technical and technological factors. And so? And so the designer sensibility is involved. And this ability much depends on his DNA, his training - general and specific - closely linked to his studies and to his willingness to learn both from general theories and from successful examples of bold "doing": sometimes wise, sometimes reckless. Nevertheless, always ready to dare try, because, beyond the number and the measurable parameters that today we cannot escape, the "lucky" fact remains that hitherto nobody has found out the infallible algorithm for "architectural quality". So, the method implicitly suggested by fairly analyzing other results (errors included) assumes, in the array of interpretations that characterizes the cultural climate of today, the value of the only available method for self-improvement.

\section{References}

[1] Minutoli, F., Lione, R., A new concept of curtain wall. Proc. of the $40^{\text {th }}$ Iahs World Congress on Housing: Sustainable Housing Construction, Coimbra: Instituto de Investigacao e Desenvolvimento Tecnologico em Ciencias de Construcao, 2014.

[2] Minutoli, F., Un cambio d'abito per il recupero di involucri esistenti: potenzialità dei tessuti. Proc. of the $30^{\text {th }}$ Int. Conf. Quale sostenibilità per il restauro?, Arcadia Ricerche, Venezia, pp. 691-701, 2014.

[3] Lione, R., Una seconda possibilità per i piani del colore. Proc. of the $2^{\text {nd }}$ Int. Conf. La cultura del restauro e della valorizzazione, Alinea editrice, Firenze, pp. 1261-1268, 2014.

[4] Fiandaca, O., Lione, R., Minutoli, F., Strategie di gestione e manutenzione. Teoria v/s prassi, InBo, 3(5), pp. 57-70, 2012.

[5] Vivian, A., Recupero di un borgo rurale. Recupero edilizio. Strategie per il riuso e tecnologie costruttive, Arketipo, Sole 24 Ore, Milano, p. 239, 2011.

[6] Nolesini, F., Riqualificazione di una casa unifamiliare. Recupero edilizio. Strategie per il riuso e tecnologie costruttive, Arketipo, Sole 24 Ore, Milano, pp. 175-185, 2011. 